\title{
PENGEMBANGAN KURIKULUM TERINTEGRASI DI SEKOLAH/MADRASAH
}

\author{
Khalid Rahman ${ }^{1}$
}

\begin{abstract}
Abstrak
The procedures and attributes are must fulfilled to integrated curriculum development of schools or madrasah that consist: (1) the concept of integrated curriculum development is conducted at SMAN 10 Malang, consists of the integrated conception of vision and mission, institutional integration, the integration of curriculum and learning by models that are suitable to within single disciplines, across several disciplines, and inside the mind of the learner; (2) planning of integrated curriculum that is used the rational-interaction model, and deductive rational model to divide roles between the principal of school and the teachers, and to organize educational components that are supporting the integrated curriculum development; (3) implementation for integrated curriculum is carried out with the learning process in classroom, that prioritize the methods of problem solving, project methods, teaching units, inquiry, discovery, thematic approach, media of learning and sources of learning that are varied; (4) evaluation for integrated curriculum is conducted with control function and supervision by the principal, while the teachers assess students that is based on three domains, namely cognitive, affective and psychomotor, then all of domains are manifested to form of test instruments and non-test.
\end{abstract}

Keywords: Curriculum Development, Integrated Curriculum

\section{A. Pendahuluan}

Kurikulum sebagai pedoman pelaksanaan pengajaran dan pembelajaran memiliki peran yang penting untuk mensukseskan tujuan pendidikan. Pendidikan yang berkualitas akan terwujud bila kurikulum yang disusun dan dikembangkan juga berkualitas.

Kurikulum yang dirancang dan dikembangkan oleh sekolah/madrasah sudah seharusnya relevan dengan kebutuhan masyarakat. Sebab kurikulum dipersiapkan dan dikembangkan untuk mencapai tujuan pendidikan, yakni

1 Dosen Universitas Brawijaya Malang 
mempersiapkan peserta didik agar mereka dapat hidup di masyarakat. (Wina Sanjaya, 2009: 10) Sebagaimana peran sekolah yang berupaya menjadi laboratorium kehidupan sosial masyarakat, sehingga peserta didik yang telah berproses di sekolah tersebut diharapkan telah siap untuk terjun dan berbaur dalam kehidupan sosial masyarakat sesungguhnya.

Dalam pengembangan kurikulum, komponen isi kurikulum yang berupa materi-materi pelajaran selalu diupayakan disajikan lebih mudah untuk dicerna oleh peserta didik dan lebih memberikan pengetahuan yang komprehensif. Selain itu, relevansi penyajian materi kurikulum harus tetap diutamakan, sehingga materi-materi yang disajikan mampu mendorong peserta didik untuk melahirkan cara berpikir yang lebih dapat memacu kecerdasannya. Sesungguhnya penyajian setiap materi kurikulum dalam bentuk mata pelajaran-mata pelajaran ada kaitannya dengan pembentukan cara berpikir peserta didik. (Lias Hasibuan, 2010: 55)

Adapun yang menjadi permasalahan pokok mengenai kurikulum adalah bagaimana mendesain kurikulum yang benar-benar dapat dijadikan pedoman untuk mencapai tujuan-tujuan pendidikan yang sekaligus menjadi tujuan hidup masyarakat. Hal ini penting diperhatikan karena pendidikan selalu terkait dengan kehidupan, pendidikan tidak hanya untuk pendidikan akan tetapi pendidikan untuk kehidupan. Karena itu, tujuan pendidikan harus dirancang berdasarkan pandangan-pandangan hidup dan sekaligus menjadi tujuan-tujuan hidup masyarakat. Setiap praktik pendidikan diarahkan pada pencapaian tujuan-tujuan tertentu, apakah berkenaan dengan penguasaan pengetahuan, pengembangan pribadi, kemampuan sosial, ataupun kemampuan bekerja.

Tulisan ini merupakan hasil penelitian yang berusaha mengurai kesenjangan teoritis pengembangan kurikulum terintegasi dan prakteknya di sekolah/madrasah yang benar-benar menerapkan pengembangan kurikulum terintegrasi. Dengan harapan akan dipertemukan konstribusi teoritis dan praktis untuk mudah dipahami pengembangan kurikulum terintegrasi bagi sekolah atau madrasah yang membutuhkan. 


\section{B. Pembahasan Teori Pengembangan Kurikulum Terintegrasi}

Kurikulum terintegrasi (integrated curriculum) lebih memandang bahwa dalam suatu pokok bahasan harus integrated atau terpadu secara menyeluruh. Keterpaduan ini dapat dicapai melalui pemusatan pelajaran pada satu masalah tertentu dengan alternatif pemecahan melalui berbagai disiplin ilmu atau mata pelajaran yang diperlukan sehingga batas-batas antara mata pelajaran dapat ditiadakan. Keberadaan proses pembelajaran tidak terfokus pada mempelajari mata pelajaran-mata pelajaran, melainkan mata pelajaran-mata pelajaran itu hanya dijadikan sarana untuk mendekati permasalahan yang menjadi fokus kajian. Hal ini, dapat memungkinkan setiap peserta didik memperoleh pengalaman belajar yang sesuai dengan minat dan bakatnya masing-masing, dan secara psikologis dapat menjadi sarana pengembangan pribadi yang utuh. (Muhammad Ali, 2009: 58) Namun mata pelajaran yang diampu oleh pendidik saat mata pelajaran berlangsung menjadi pedoman dan pusat pengintegrasian topik, sehingga ruh pembelajaran dan pengajaran tidak meninggalkan mata pelajaran yang telah ditentukan pemerintah untuk memenuhi tujuan pendidikan nasional.

Pengembangan kurikulum terintegrasi memberikan kesempatan pada peserta didik untuk belajar secara kelompok maupun secara individu, lebih memberdayakan masyarakat sebagai sumber belajar, memungkinkan pembelajaran bersifat individu terpenuhi, serta dapat melibatkan peserta didik dalam mengembangkan program pembelajaran. Bahan pelajaran dalam kurikulum ini akan bermanfaat secara fungsional serta dalam pembelajaran akan dapat membentuk kemampuan peserta didik secara proses maupun produk. Bahan pelajaran selalu aktual sesuai perkembangan dan kebutuhan masyarakat maupun peserta didik sebagai individu yang utuh sehingga bahan pelajaran yang dipelajari selalu sesuai dengan bakat, minat, dan potensi peserta didik. (Rusman, 2009: 65) Kurikulum ini juga mempertimbangkan semua aspek, sesuai dengan sistem kepercayaan, sistem nilai, sistem kebutuhan yang terpadu dalam masyarakat.

The concept of integrated curricula continues the conversation with practical ways to transform that learning into real-life experiences that transfer effortlessly into future applications. (Robin Fogarty, 2009: 7) 
Dalam kurikulum terintegrasi, pelajaran disesuaikan dengan kehidupan peserta didik di luar sekolah yaitu kehidupan nyata. Belajar berangkat dari suatu pokok masalah yang harus dipecahkan. Masalah tersebut kemudian dinamakan unit. Belajar berdasarkan unit bukan hanya menghafal sejumlah fakta, akan tetapi juga mencari dan menganalisis fakta sebagai bahan untuk memecahkan masalah. Belajar melalui pemecahan masalah itu diharapkan perkembangan peserta didik tidak hanya terjadi pada segi intelektual saja akan tetapi seluruh aspek seperti sikap, emosi, atau keterampilan. (Wina Sanjaya, 2009: 67)

Sedangkan menurut Robin Fogarty dalam Trianto, model kurikulum terintegrasi dikelompokkan menjadi 3 (tiga) klasifikasi pengintegrasian kurikulum, sebagai berikut:

a. Pengintegrasian di dalam Satu Disiplin Ilmu

Model ini merupakan integrasi yang mentautkan dua atau lebih bidang ilmu yang serumpun. Misalnya di bidang Ilmu Alam, mentautkan antara dua tema dalam fisika dan biologi yang memiliki relevansi, atau antara tema dalam kimia dan fisika. Contoh: tema metabolisme dapat ditinjau dari biologi maupun kimia. Begitupun dengan tematema yang relevan pada Ilmu Sosial seperti antara sosiologi dan geografi. Jadi sifat perpaduan dalam model ini hanya dalam satu rumpun bidang ilmu saja (inter-disipliner).

b. Pengintegrasian Beberapa Disiplin Ilmu

Model ini merupakan integrasi yang mentautkan antar disiplin ilmu yang berbeda. Misalnya antara tema yang ada dalam bidang ilmu sosial dengan bidang ilmu alam. Sebagai contoh, tema energi merupakan tema yang dapat dikaji dari bidang ilmu yang berbeda baik dalam bidang ilmu sosial (tentang kebutuhan energi dalam masyarakat), dan bidang ilmu alam (tentang bentuk-bentuk energi dan teknologinya).

c. Pengintegrasian di dalam Satu dan Beberapa Disiplin Ilmu

Model ini merupakan integrasi yang paling kompleks karena mentautkan antar disiplin ilmu yang serumpun sekaligus bidang ilmu yang berbeda. Misalnya, antara tema yang ada dalam bidang 
ilmu sosial, bidang ilmu alam, teknologi maupun ilmu agama. Sebagai contoh, tema rokok merupakan tema yang dapat dikaji dari berbagai bidang ilmu yang berbeda. (Trianto, 2007: 40)

\section{Tabel 1: Klasifikasi Pengintegrasian Kurikulum}

\begin{tabular}{lll}
\hline No. Klasifikasi Pengintegrasian & Model Kurikulum Terintegrasi \\
\hline 1) & $\begin{array}{l}\text { Pengintegrasian kurikulum } \\
\text { di dalam satu disiplin ilmu } \\
\text { (interdisiplin ilmu) }\end{array}$ & $\begin{array}{l}\text { The Cellular model (model tergambarkan), } \\
\text { the connected model (model terhubung), } \\
\text { the nested model (model bersarang) }\end{array}$ \\
2) & $\begin{array}{l}\text { Pengintegrasian kurikulum } \\
\text { beberapa disiplin ilmu (antar } \\
\text { disiplin ilmu) }\end{array}$ & $\begin{array}{l}\text { The squenced model (model terurut), the } \\
\text { shared model (model terbagi), the webbed } \\
\text { model (model terjaring), the threaded } \\
\text { model (model tertali), the integrated model } \\
\text { (model terpadu) }\end{array}$ \\
3) & $\begin{array}{l}\text { Pengintegrasian kurikulum di } \\
\text { dalam dan beberapa disiplin ilmu } \\
\text { (inter dan antar disiplin ilmu) }\end{array}$ & $\begin{array}{l}\text { The networked model (model terbenam), } \\
\text { the nodel jaringan) }\end{array}$ \\
\hline
\end{tabular}

(Sumber: Trianto, 2007: 42 yang diadopsi dari Fogarty)

Secara ideal hasil yang diinginkan dalam pengembangan kurikulum ini membentuk kemampuan peserta didik yang terintegrasi yang menggambarkan manusia yang harmonis sesuai dengan kebutuhan masyarakat maupun sesuai dengan tuntutan potensi peserta didik. Kemampuan dalam memecahkan masalah secara ilmiah merupakan bagian dari karakteristik pembelajaran dalam kurikulum ini. Masalah yang diselesaikan biasanya berkaitan dengan masalah sosial, pekerjaan, maupun masalah-masalah yang sifatnya aktual. Dengan demikian, informasi dan kemampuan yang dipelajari peserta didik akan selalu sesuai dengan perkembangan sosial budaya maupun dengan ilmu pengetahuan dan teknologi, bahkan kurikulum ini memberikan kesempatan pada peserta didik untuk belajar sesuai dengan kemampuan, bakat, dan minat peserta didik.

Dalam pelaksanaan pengembangan kurikulum terintegrasi, maka harus mengacu pada proses pengembangan kurikulum, sehingga akan didapat alur pengembangan kurikulum terintegrasi sebagai berikut: (1) 
perencanaan kurikulum terintegrasi, (2) pelaksanaan kurikulum terintegrasi, dan (3) evaluasi kurikulum terintegrasi.

\section{1) Perencanaan Kurikulum Terintegrasi}

Perencanaan bertujuan untuk mencapai seperangkat operasi yang konsisten dan terkoordinasi guna memperoleh hasil-hasil yang diinginkan. Secara mendasar, perencanaan adalah suatu proses intelektual yang melibatkan pembuatan keputusan. Proses ini menuntut prediposisi mental untuk berpikir sebelum bertindak, berbuat berdasarkan kenyataan bukan perkiraan, dan berbuat sesuatu secara teratur. (Oemar Hamalik, 2008: 134) Hal ini, menekankan bahwa perencanaan dalam pengembangan kurikulum terintegrasi merupakan suatu keharusan yang tidak terelakkan. Begitu juga harus mampu mengintegrasi perencanaan dengan tujuan pendidikan di masing-masing skala, apakah skala nasional, institusional, kurikuler dan intruksional.

Untuk menyusun perencanan kurikulum terintegrasi, maka harus memperhatikan bentuknya sebagai berikut: Pertama, unit merupakan satu kesatuan dari seluruh bahan pelajaran. Faktor yang menyatukan adalah masalah-masalah yang akan diselidiki dan dipecahkan oleh peserta didik. Segala aktivitas peserta didik harus berkaitan dengan pokok masalah tersebut. Seluruh bahan pelajaran dipergunakan untuk memecahkan masalah yang dihadapi.

Kedua, unit didasarkan pada kebutuhan peserta didik baik yang bersifat pribadi maupun sosial, baik yang menyangkut jasmani dan rohani. Kebutuhan peserta didik biasanya ditentukan oleh latar belakang masyarakatnya. Dengan sistem unit ini, akan meningkatkan perkembangan sosial peserta didik dengan banyak memberikan kesempatan bekerjasama dalam kelompok. Ketiga, dalam unit peserta didik dihadapkan pada berbagai situasi yang mengandung permasalahan yang berhubungan dengan kehidupan sehari-hari dan dikaitkan dengan pelajaran di sekolah sesuai dengan tingkat kemampuan peserta didik.

Keempat, unit mempergunakan dorongan-dorongan sewajarnya pada diri peserta didik dengan melandaskan diri pada teori-teori belajar. Peserta didik diberi kesempatan melakukan berbagai kegiatan sesuai dengan minatnya. Dalam merancang unit peserta didik juga harus diikutsertakan 
untuk menentukan pokok-pokok masalahnya. Kelima, pelaksanaan unit sering memerlukan waktu yang relatif lebih lama daripada pelajaran biasa di kelas. (Burhan Nurgiyantoro, 119)

\section{2) Pelaksanaan Kurikulum Terintegrasi}

Pelaksanaan kurikulum direalisasikan dalam proses belajar mengajar sesuai dengan prinsip-prinsip dan tuntutan kurikulum yang telah dikembangkan bagi suatu jenjang pendidikan atau sekolah/madrasah tertentu.

Kegiatan proses belajar mengajar erat kaitannya dengan tugas-tugas seorang guru, kegiatan-kegiatan tersebut antara lain: (a) menyusun rencana pelaksanaan program/unit, (b) menyusun jadwal pelaksanaan kegiatan dan jadwal pelajaran, (c) pengisian daftar penilaian kemajuan belajar dan perkembangan peserta didik, dan (d) pengisian buku laporan pribadi peserta didik.

Dalam pendekatan pelaksanaan kurikulum terintegrasi, peserta didik adalah pembuat keputusan dan para pemecah masalah. Proses dipandang sebagai sentral untuk menjelaskan tingkah laku. Peserta didik itu berbeda satu sama lain, sedangkan masalah merupakan kunci dimana proses dimulai, karena itu pula cara penyelesaian masalah pun berbeda satu sama lain, tidak ada dua cara yang sama. Para peserta didik bukan saja dikembangkan sebagai suatu kepribadian yang bulat, akan tetapi juga dipersiapkan sebagai pribadi yang mampu berperan di masyarakat. Selain dari itu, pendekatan ini memungkinkan kerjasama antara sekolah dan masyarakat. (Oemar Hamalik, 2008: 60-62)

Pelaksanaan kurikulum ini guru dituntut untuk memiliki kemampuan mengimplementasikan berbagai strategi belajar mengajar yang sesuai dengan karakteristik kurikulum tersebut. Pembelajaran yang mungkin banyak digunakan seperti pemecahan masalah, metode proyek, pengajaran unit, inquiry, discovery, dan pendekatan tematik yang dilakukan dalam pembelajaran kelompok maupun secara perorangan. Pembelajaran tematik juga merupakan salah satu model dalam pembelajaran terpadu (integrated instruction) yang merupakan suatu sistem pembelajaran yang memungkinkan peserta didik, baik secara individual maupun kelompok, aktif 
menggali dan menemukan konsep serta prinsip-prinsip keilmuan secara holistik, bermakna dan autentik. Pendekatan pembelajaran terpadu lebih menekankan pada penerapan konsep belajar sambil melakukan sesuatu (learning by doing). Peserta didik akan memahami konsep-konsep yang mereka pelajari melalui pengalaman langsung dan menghubungkannya dengan konsep lain yang telah dipahaminya. (Rusman, 2009: 254)

Kurikulum terintegrasi terwujud pada unit-unit pembelajaran, yang masing-masing unit didukung oleh sejumlah mata pelajaran atau bidang studi. Tiap unit merupakan suatu masalah yang luas dan perlu dipecahkan, dan pemecahannya membutuhkan bahan dari setiap bidang studi. Itu sebabnya, urutan bahan, ruang lingkup dan penempatan bahan untuk setiap unit harus dirancang berdasarkan kebutuhan unit dan sistem instruksional yang dilaksanakan. . (Oemar Hamalik, 2008: 129)

Secara lebih rinci menurut Lias Hasibuan, penyajian kurikulum terintegrasi dapat dilakukan dalam bentuk:

a) "Unit curriculum", yaitu kurikulum unit dimana pada tingkat tertentu mengintegrasikan sejumlah mata pelajaran dan difungsikan menjadi suatu komponen untuk mengkaji suatu topik yang sedang dipelajari, pembelajarannya dengan pendekatan multi disipliner.

b) "Project curriculum", yaitu kurikulum dimana materi tertentu yang relevan dari mata pelajaran dipadukan untuk menyelesaikan suatu proyek dalam proses kegiatan belajar-mengajar atau untuk memecahkan suatu masalah. (Lias Hasibuan, 2010: 58)

Pelaksanaan pengembangan kurikulum yang dilakukan dengan menggunakan metode proyek. Dalam hal ini peserta didik diberi kesempatan untuk merencanakan dan melakukan atau melaksanakan proyek kegiatan, sesuai dengan minat dan kebutuhannya. Killpatrick dalam Muhammad Ali, membagi proyek-proyek yang dapat dilaksanakan sebagai berikut:

a) Proyek permainan seperti drama, menari atau sejenisnya

b) Proyek ekskursi seperti karya wisata ke tempat-tempat bersejarah, kebun biologi atau sejenisnya.

c) Proyek cerita seperti membaca cerita, mendengarkan cerita atau sejenisnya. 
Proyek pekerjaan tangan seperti membuat prakarya atau sejenisnya. (Muhammad Ali, 2009: 119) Sedangkan menurut Nana Syaodih (2005: 97) pengembangan kurikulum terintegrasi prosesnya, sebagai berikut:

a) Menentukan tema-tema (topik) yang membentuk satu kesatuan (unifying theme), yang dapat terdiri atas ide atau konsep besar yang dapat mencakup semua ilmu atau suatu proses kerja ilmu, fenomena alam, atau masalah sosial yang membutuhkan pemecahan secara ilmiah.

b) Menyatukan kegiatan belajar dari beberapa disiplin ilmu. Kegiatan belajar melibatkan isi dan proses dari satu atau beberapa ilmu sosial atau perilaku yang mempunyai hubungan dengan tema yang dipilih/ dikerjakan.

c) Menyatukan beberapa cara atau metode belajar. Kegiatan belajar ditekankan pada pengalaman konkret yang bertolak dari minat dan kebutuhan murid serta disesuaikan dengan keadaan setempat.

Proses pemilihan topik yang dijadikan isi kurikulum terintegrasi dilakukan langkah-langkah sebagai berikut:

a) Mengindentifikasi topik-topik yang dijadikan bahan untuk dipelajari peserta didik agar tercapai tujuan yang dirumuskan. Cara yang ditempuh untuk mengidentifikasi topik-topik yang dijadikan bahan adalah:

1) Menganalisis setiap tujuan untuk mengetahui hakikat maksud yang ingin dicapai dan menganalisis sumber tujuan itu dari tujuan yang lebih umum atau lebih tinggi.

2) Mengidentifikasi topik yang diperkirakan dapat dijadikan bahan di dalam proses pencapaian tujuan.

b) Memilih topik-topik yang paling relevan, fungsional, efektif dan komprehensif bagi pencapaian tujuan yang telah diidentifikasi. (Muhammad Ali, 2009: 101)

Dalam penerapan pengembangan kurikulum terintegrasi yang berbentuk pembelajaran terintegrasi, maka ada beberapa hal yang perlu dilakukan yaitu: 
a) Tujuan Pembelajaran Terintegrasi

Tujuan pokok pembelajaran terintegrasi, yaitu: 1) meningkatkan efisiensi dan efektivitas pembelajaran, 2) meningkatkan minat dan motivasi, 3) beberapa kompetensi dasar dapat dicapai sekaligus. (Trianto, 2007: 104)

b) Klasifikasi Pengintegrasian Tema/Pokok Materi

Pembelajaran terintegrasi dibedakan berdasarkan pola pengintegrasian materi atau tema. Berdasarkan pola tersebut Fogarty mengemukakan bahwa terdapat sepuluh model pembelajaran terintegrasi, yaitu: (1) the fragmented model (model tergambarkan), (2) the connected model (model terhubung), (3) the nested model (model tersarang), (4) the squenced model (model terurut), (5) the shared model (model terbagi), (6) the webbed model (model terjaring), (7) the threaded model (model tertali), (8) the integrated model (model terpadu), (9) the immersed model (model terbenam), (10) the networked model (model jaringan).

\section{c) Pemaduan Konsep dalam Pembelajaran Terintegrasi}

Salah satu kunci pembelajaran terintegrasi yang terdiri dari beberapa bidang kajian adalah menyediakan lingkungan belajar yang menempatkan peserta didik agar mendapatkan pengalaman belajar yang dapat menghubungkan konsep-konsep dari berbagai bidang kajian. Pembelajaran terintegrasi diawali dengan penentuan tema, karena penentuan tema akan membantu peserta didik dalam beberapa aspek, yaitu:

1) Peserta didik yang bekerjasama dengan kelompoknya akan lebih bertanggung jawab, disiplin dan mandiri.

2) Peserta didik menjadi lebih percaya diri dan termotivasi dalam belajar bila mereka berhasil menerapkan apa yang telah dipelajarinya.

3) Peserta didik lebih memahami dan lebih mudah mengingat karena mereka mendengar, berbicara, membaca, menulis dan melakukan kegiatan penyelidikan masalah yang sedang dipelajarinya.

4) Memperkuat kemampuan berbahasa peserta didik. 
5) Belajar akan lebih baik bila peserta didik terlihat secara aktif melalui tugas proyek, kolaborasi dan berinteraksi dengan teman, guru dan dunia nyata. (Trianto, 2007: 110)

d) Strategi Pelaksanaan Pembelajaran Terintegrasi

Keberhasilan pembelajaran terintegrasi akan lebih optimal jika perencanaan mempertimbangkan kondisi dan potensi peserta didik (minat, bakat, kebutuhan dan kemampuan).

Langkah-langkah pengembangan pembelajaran terintegrasi:

1) Menetapkan bidang kajian yang akan dipadukan.

2) Mempelajari standar kompetensi dan kompetensi dasar dari bidang kajian yang akan dipadukan.

3) Penentuan tema pemersatu antar standar kompetensi dan kompetensi dasar.

4) Membuat matriks keterhubungan kompetensi dasar dan tema/topik pemersatu.

5) Penjabaran kompetensi-kompetensi dasar ke dalam materi pokok pencapaian hasil belajar.

6) Menyusun silabus pembelajaran terintegrasi, dikembangkan dari berbagai materi pokok bidang kajian.

7) Menyusun rencana pelaksanaan pembelajaran. Rencana pelaksanaan pembelajaran tersebut merupakan realisasi dari pengalaman belajar peserta didik yang telah ditentukan pada silabus pembelajaran terintegrasi.

\section{3) Evaluasi Kurikulum Terintegrasi}

Evaluasi pengembangan kurikulum dapat dipandang sebagai proses pembuatan keputusan-keputusan tentang kurikulum di dalam sekolah atau proses pengajaran yang dibatasi oleh minat-minat pihak luar, seperti orang tua, karyawan, masyarakat lokal atau masyarakat luas. (Oemar Hamalik, 2008: 141) 
Peranan evaluasi kurikulum bagi pimpinan, berkenaan dengan hal yaitu: evaluasi sebagai moral judgement, evaluasi dan penentuan keputusan, serta evaluasi dan konsensus nilai. (Nana Syaodih Sukmadinata, 2005: 180) Bagi guru, penyelenggaraan evaluasi hasil penerapan pengembangan kurikulum dalam satu semester, yaitu: evaluasi formatif dan evaluasi sumatif. Kedua jenis evaluasi ini dilaksanakan oleh guru dengan tujuan untuk mengetahui keberhasilan proses penerapan kurikulum di kelas. (Arikunto, 1987: 142)

\section{a) Evaluasi Formatif}

Evaluasi formatif adalah evaluasi atau penilaian yang dilakukan setelah satu pokok bahasan selesai dipelajari oleh peserta didik. Evaluasi formatif terutama dimaksudkan untuk memberikan umpan balik kepada guru mengenai keberhasilan proses belajar mengajarnya. Evaluasi formatif ini dapat dilaksanakan dengan tes tertulis maupun lisan.

\section{b) Evaluasi Sumatif}

Evaluasi sumatif adalah tes yang diselenggarakan oleh guru setelah menempuh satu jangka waktu tertentu. Dalam pelaksanaan tes sumatif ini sering disebut dengan ulanngan atau ujian semester, atau ulangan umum nasional dan biasanya diselenggarakan secara serempak untuk seluruh sekolah. Dalam evaluasi sumatif, evaluasi berfungsi untuk menetapkan keseluruhan penilaian program. (Rusman, 2009: 101)

Evaluasi kurikulum memegang peranan penting baik dalam penentuan kebijaksanaan pendidikan pada umumnya, maupun pada pengambilan keputusan dalam pengembangan kurikulum. Hasil-hasil evaluasi dapat digunakan oleh para pemegang kebijaksanaan pendidikan dan para pengembang kurikulum dalam memilih dan menetapkan kebijaksanaan pengembangan sistem pendidikan dan pengembangan model kurikulum yang digunakan. (Nana Syaodih Sukmadinata, 2005: 172)

Dalam evaluasi kurikulum terintegrasi, penilaian pencapaian kompetensi dasar peserta didik dilakukan berdasarkan indikator. Penilaian dilakukan dengan menggunakan tes dan non tes dalam bentuk tertulis maupun lisan, pengamatan kinerja, pengukuran sikap, penilaian hasil karya berupa tugas, proyek dan/atau produk, penggunaan portofolio dan 
penilaian diri. Adapun penilaian atau evaluasi kurikulum terintegrasi, sebagaimana bagan berikut. (Trianto, 2007: 94)

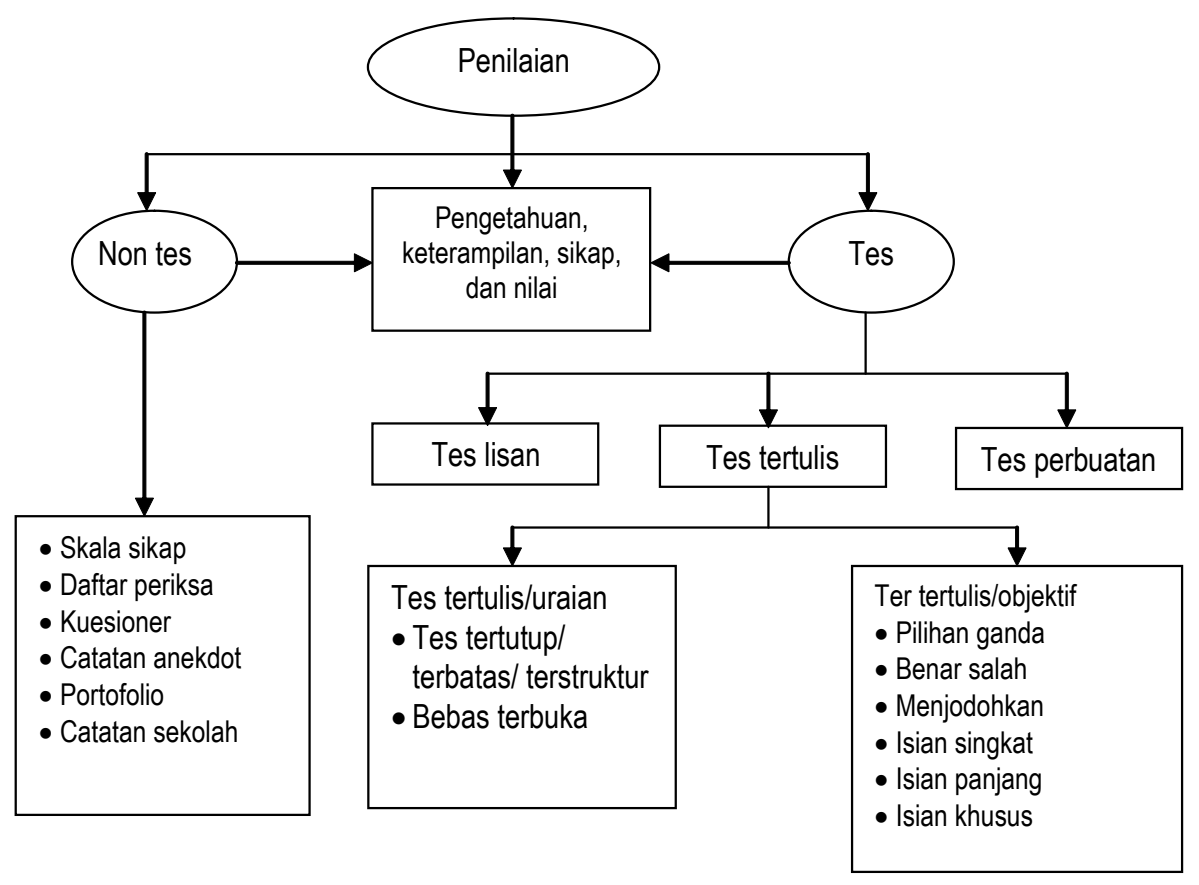

\section{Bagan 1: Model Evaluasi Kurikulum Terintegrasi}

(Dikutip dari Trianto, 2007:94)

Untuk penilaian non-tes dapat dilakukan dengan menganalisis masalah dan memaparkan pemecahannya (problem solving). Dalam pemaparan ini dapat ditekankan pentingnya penggunaan kosa kata yang tepat, sistematika penyajian dan pengetahuan lain untuk memecahkan masalah yang ditentukan. Bisa juga melalui observasi dan inferensi, perkembangan berpikir kritis dan kreatif serta keterampilan berinkuiri peserta didik dapat dievaluasi. 


\section{PELAKSANAAN PENGEMBANGAN KURIKULUM TERINTEGRASI \\ a. Konsep Pengembangan Kurikulum Terintegrasi}

Berdasarkan pada hasil penelitian, penulis mengurai pengembangan kurikulum terintegrasi yang terjadi di lapangan yaitu sekolah/madrasah, yang kemudian dianalisis dengan kajian teori yang telah diulas sebelumnya, sebagai berikut:

\section{Konsepsi Visi dan Misi yang Terintegrasi}

Visi dan misi yang dibangun sekolah/madrasah merupakan penafsiran dari cita-cita luhur pendidikan nasional yang diamanahkan dalam UU No. 20 Tahun 2003. Dari penafsiran tersebut terbentuklah visi dan misi lembaga yaitu "Menjadi sekolah unggul, menghasilkan SDM yang bertaqwa, cerdas, berprestasi, mandiri dan berdaya saing tinggi serta berbudaya lingkungan."

Visi dan misi di atas menjadi acuan dalam pengembangan kurikulum, bahwa untuk mengembangkan tujuan kurikulum harus merupakan bagian penurunan dari visi dan misi. Karena proses pengembangan kurikulum dimulai dengan visi dan misi lembaga (asumsi-asumsi filosofis) sebagai sistem nilai atau padangan hidup. Berdasarkan visi dan misi itulah selanjutnya ditentukan tentang pengembangan struktur kurikulum sebagai arah pembentukan hakikat pengetahuan, sosiokultutral, kondisi peserta didik, dan perkembangan teori pembelajaran. (Wina Sanjaya, 2009: 36-37)

Perumusan unsur-unsur visi yang nantinya menjadi garis besar haluan sekolah/madrasah dalam menentukan misi dan tujuan, hingga pada pengembangan kurikulum, kegiatan belajar mengajar dan pembentukan karakter anak didik. Bila dianalisis lebih jauh semangat integrasi pada perumusan unsur-unsur visi dan misi sekolah sudah nampak pada keinginan sekolah membentuk peserta didiknya bertakwa, cerdas, berdaya saing, berprestasi, mandiri dan berbudaya lingkungan. Unsur-unsur ini sangat lengkap ditanamkan pada peserta didik dan komprehensif, karena menyentuh semua aspek yaitu aspek spiritual, aspek rasionalitas akademik, aspek sosial interaktif, dan aspek alamiah/nature. 


\section{Integrasi Kelembagaan}

Integrasi kelembagaan di sini dimaksudkan bahwa sekolah diharuskan memiliki asrama (boarding school/dormitory) yang keberadaannya berfungsi untuk menunjang kesuksesan pelaksanaan kurikulum dan pengembangannya. Pemahaman pentingnya ada asrama dilatarbelakangi kegiatan siswa selama 24 jam sehari bila diperinci siswa berada di sekolah untuk belajar hanya menghabiskan waktu \pm 8 jam, sedangkan 16 jam lainnya lebih banyak dihabiskan di rumah yang mana kemungkinan untuk belajar di rumah sangat sedikit. Hanya siswa tertentu atau orang tua siswa tertentu yang menyadari bahwa belajar itu penting, kalaupun beberapa siswa belajar di rumah juga tanpa rencana dan rekayasa kurikulum yang baik. Ada juga yang mana siswa akan belajar di rumah bila dia diberikan PR (pekerjaan rumah) atau tugas mata pelajaran tertentu dari sekolah. Mungkin juga ada yang menganggap siswa di rumah baik dia disibukkan dengan bermain, jalan-jalan, membantu orang tua, dan berinteraksi dengan teman-temannya, itu adalah bagian dari proses belajar hidup mengenal kondisi sosiologisnya. Namun yang menjadi perhatian beberapa pemerhati pendidikan, alahkan lebih baiknya bila proses belajar hidup yang dilakukan siswa di rumah atau dimanapun siswa menghabiskan waktunya 16 jam tersebut direncanakan dan direkayasa sebaik mungkin dalam bingkai kurikulum untuk membantu perkembangan siswa baik itu kecerdasan, keterampilan, skill motorik, dan psikologinya menjadi lebih baik, untuk masa depannya serta mengurangi interaksi siswa dengan kegiatan-kegiatan negatif yang bisa merusak moralnya.

Desain kelembagaan yang terintegrasi di sekolah/madrasah tidak terjadi dikotomi pengambilan kebijakan program akademik, sehingga program yang ada di sekolah dan asrama saling mendukung keberadaannya, saling mempengaruhi, dan bahkan menjadi satu program yang tidak tepisahkan karena satu kesatuan. Tidak terjadi pemahaman ini program asrama, dan ini program sekolah sehingga terkesan tanggung jawab program terpisah, tapi yang terjadi program asrama adalah program sekolah juga dan program sekolah juga adalah program asrama sehingga tidak ada beda. 


\section{Integrasi Kurikulum dan Pembelajaran}

Integrasi kurikulum di sekolah/madrasah berlandaskan kurikulum nasional yang termaktub pada SNP tahun 2005 dan kurikulum internasional Cambridge atau CIE (Cambridge International Examination) Center bagi sekolah/madrasah yang menginginkan standar internasional demi tuntutan persaingan global, atau mungkin standar dari negara lain yang dianggap telah maju dalam bidang pendidikannya. Kurikulum terintegrasi yang dilaksanakan di sekolah/madrasah secara struktur formal, paling tidak terdapat tiga jenis, yaitu (a) integrasi kurikulum nasional (KTSP) dan internasional (IGCSE), (b) integrasi kurikulum intrakurikuler (KTSP/IGCSE) dan ekstrakurikuler (L2L/youth entrepreneurship program/adiwiyata/ program dormitory), dan (c) integrasi kurikulum dalam pembelajaran (within sigle discipline, across several disciplines, dan inside the mind of the learner).

a) Integrasi kurikulum nasional (KTSP) dan internasional (IGCSE)

Integrasi kurikulum nasional (KTSP) dan internasional (IGCSE) di sekolah/madrasah dilakukan sejak pada perencanaan kurikulum setelah melakukan workshop pengembangan kurikulum tahunan. Para guru dikelompokkan pada setiap rumpun mata pelajarannya untuk melakukan: analisis, penyelarasan, pengkombinasian dan pengintegrasian kurikulum KTSP dan IGCSE, baik dalam standar kompetensi (SK), kompetensi dasar (KD), topik dan sub materi. Salah satu contoh hasil dari integrasi yang dilakukan guru mata pelajaran biologi, sebagaimana tabel berikut: 
Tabel 2: Contoh Hasil Integrasi Kurikulum KTSP dan IGCSE

\begin{tabular}{|c|c|c|c|}
\hline \multicolumn{2}{|l|}{ KTSP } & \multicolumn{2}{|r|}{ IGCSE } \\
\hline SK/KD & Materi & Topic & Core/Supplement \\
\hline Grade: XI & & & \\
\hline $\begin{array}{l}\text { Menganalisis hubungan } \\
\text { antara komponen } \\
\text { ekosistem, perubahan } \\
\text { materi dan energi serta } \\
\text { peranan manusia dalam } \\
\text { keseimbangan ekosistem. }\end{array}$ & $\begin{array}{l}\text { Ekosistem } \\
\text { - Komponen } \\
\text { ekosistem } \\
\text { - Aliran }\end{array}$ & $\begin{array}{l}\text { Section } \\
\text { relationships of } \\
\text { organisms with } \\
\text { one another } \\
\text { and with their } \\
\text { environment }\end{array}$ & $\begin{array}{l}\text { - state that the Sun is } \\
\text { the principal source of } \\
\text { energy input to biological } \\
\text { systems } \\
\text { - describe the non-cyclical } \\
\text { nature of energy flow }\end{array}$ \\
\hline $\begin{array}{l}\text { 4.1 Mendeskripsikan } \\
\text { peran komponen } \\
\text { ekosistem dalam } \\
\text { aliran energi dan daur } \\
\text { biogeokimia serta } \\
\text { pemanfaatan komponen } \\
\text { ekosistem bagi kehidupan }\end{array}$ & Energi & 1. Energy flow & \\
\hline
\end{tabular}

Setelah ditemukan keselarasan topik-topik pada dua kurikulum tersebut, maka guru didorong untuk mengkonsepsikan topik-topik yang ada pada kurikulum dalam bentuk lesson plan. Sub kurikulum yang merupakan topik-topik hasil penyelarasan harus mampu meng-cover kedua konten kurikulum tersebut. Berikut contoh lesson plan pada mata pelajaran biologi.

Tabel 3: Contoh Lesson Plan Kurikulum Terintegrasi

\begin{tabular}{|c|c|c|c|c|}
\hline $\begin{array}{c}\text { Competence } \\
\text { Standard/ Basic } \\
\text { Competence }\end{array}$ & $\begin{array}{l}\text { Learning } \\
\text { Objectives }\end{array}$ & Indicators & $\begin{array}{l}\text { Focusing } \\
\text { Question }\end{array}$ & Values \\
\hline \multirow[t]{2}{*}{$\begin{array}{l}\text { Students are able } \\
\text { to understand the } \\
\text { organisation and } \\
\text { maintenance of } \\
\text { the organism }\end{array}$} & $\begin{array}{l}\text { Students can } \\
\text { relate the } \\
\text { structure of the } \\
\text { following to } \\
\text { their function; } \\
\text { ciliated cells }\end{array}$ & $\begin{array}{l}\text { Define relate } \\
\text { the structure } \\
\text { of the } \\
\text { following to } \\
\text { their function; } \\
\text { ciliated cells - } \\
\text { in respiratory } \\
\text { tract etc. }\end{array}$ & $\begin{array}{l}\text { What are the } \\
\text { relate the } \\
\text { structure of the } \\
\text { following to their } \\
\text { function; ciliated } \\
\text { cells? }\end{array}$ & $\begin{array}{l}\text { Courageous } \\
\text { innovative } \\
\text { respect }\end{array}$ \\
\hline & $\begin{array}{l}\text { Students can } \\
\text { define tissue, } \\
\text { organ, organ } \\
\text { system }\end{array}$ & $\begin{array}{l}\text { Define tissue, } \\
\text { organ, organ } \\
\text { system }\end{array}$ & $\begin{array}{l}\text { What do you } \\
\text { know about } \\
\text { tissue, organ, } \\
\text { organ system }\end{array}$ & \\
\hline
\end{tabular}


Kegiatan integrasi kurikulum ini lebih kepada bagaimana mempertemukan keselarasan standar materi dan kompetensi untuk dikolaborasikan dan dilebur jadi satu kesatuan topik sub bahasan materi pokok. Hasil integrasi ini, kemudian dikembangkan dalam lesson plan dan didesain ulang untuk dimodifikasi sesuai dengan model integrasi yang sesuai dengan karakteristik materi, sehingga siap diterapkan di pembelajaran yang integratif.

b) Integrasi kurikulum intrakurikuler (KTSP/IGCSE) dan ekstrakurikuler (L2L/youth entrepreneurship program/adiwiyata/program dormitory)

Pengintegrasian kurikulum intrakurikuler dan ekstrakurikuler di sekolah/madrasah didasarkan pada pemahaman bahwa peserta didik harus memahami pelajaran-pelajaran di kelas sekaligus prakteknya dan melatih skill kemampuan akademiknya. Bentuk integrasi yang dilakukan yaitu peserta didik harus menempuh 254 JP kurikulum intrakurikuler dan 240 JP kurikulum ekstrakurikuler selama tiga tahun. Jadi struktur kurikulum terintegrasi di sekolah/madrasah, bila dirinci pada setiap tahunnya, peserta didik di kelas X menempuh 84 JP kurikulum intrakurikuler dan 80 JP kurikulum ekstrakurikuler, di kelas XI menempuh 86 JP kurikulum intrakurikuler dan 80 JP kurikulum ekstrakurikuler, dan di kelas XII menempuh 84 JP kurikulum intrakurikuler dan 80 JP kurikulum ekstrakurikuler.

Bila dirinci tiap semester maka peserta didik, di kelas X menempuh 42 jp kurikulum intrakurikuler dan 40 jp kurikulum ekstrakurikuler, di kelas XI menempuh 43 jp kurikulum intrakurikuler dan 40 jp kurikulum ekstrakurikuler, dan di kelas XII menempuh 42 jp kurikulum intrakurikuler dan 40 jp kurikulum ekstrakurikuler. Jadi hampir berimbang kurikulum secara teoritis untuk pembentukan kecerdasan kognitif dan kurikulum untuk pengembangan skill dan emosi. Belum lagi hidden curriculum yang di-manage ketika peserta didik berada di dormitory yang lebih pada pembentukan karakter dan pengembangan emosi sosial.

Program kurikulum ekstrakurikulernya terdiri dari 4 kelompok program ekstrakurikuler: a) Personal Well-Being, b) Art and Creativity, c) 
Global Citizenship, d) Community Service. Empat kelompok program ini bila dikategorikan termasuk dalam bingkai The Social Function Curriculum and Persistent Situations. Hal demikian sangat sesuai dengan jenis kurikulum terintegrasi yang diungkapkan oleh Soetopo dan Soemanto dalam Abdullah Idi, bahwa The Social Function Curriculum and Persistent Situations ini termasuk kurikulum terintegrasi yang didasarkan atas analisis kegiatan manusia dalam masyarakat. Kegiatan yang dilakukan manusia sebagai individu dan sebagai anggota masyarakat di antaranya: (a) memelihara dan menjaga keamanan masyarakat; (b) perlindungan dan pelestarian hidup, kekayaan, dan sumber alam; (c) komunikasi dan transportasi; (d) kegiatan rekreasi; (e) produksi dan distribusi barang dan jasa; (f) ekspresi rasa keindahan; (g) kegiatan pendidikan; (h) integrasi kepribadian; (i) konsumsi benda dan jasa. (Abdullah Idi, 2007: 170)

Penjelasan analisis di atas mungkin lebih mudah dengan adanya bagan sebagai berikut:

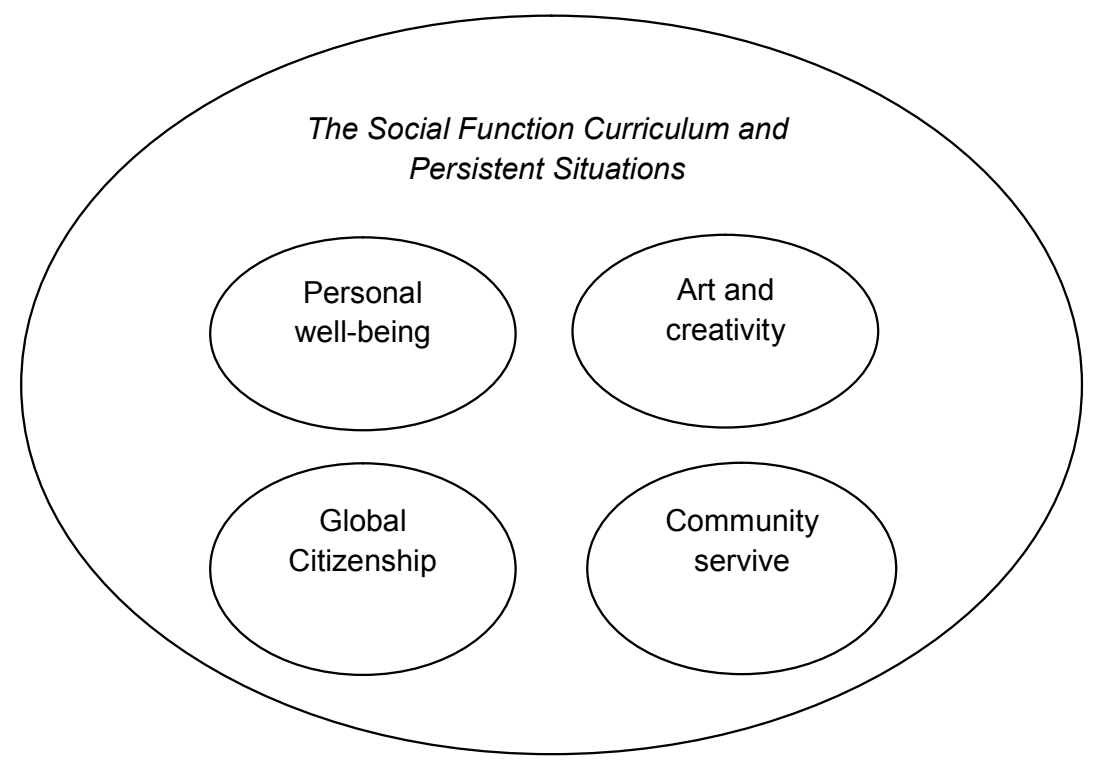

\section{Bagan 2: Kategorisasi Kurikulum Ekstrakurikuler sebagai Kurikulum Terintegrasi di Sekolah/Madrasah}

Personal well-being merupakan program kurikulum ekstrakurikuler formal yang ditetapkan, guna membentuk skill personal dan olah psikomotorik 
yang kreatif dan tangkas. Dalam kurikulum terintegrasi ada jenisnya yang sangat memperhatikan aspek skill individual yang disebut The Child Centered Curriculum, yaitu program yang mengorganisasi pengalaman belajar peserta didik yang berkisar pada empat pengaruh manusia (human Impulse), yakni: the social impulse, the constructive impulse, the impulse to investigate and to experiment, dan the expressive atau artistic impulse. (Abdullah Idi, 2007: 170).

Art and Creativity merupakan program kurikulum ekstrakurikuler formal yang diarahkan untuk mengasah kemampuan emosi artistik peserta didik, dan membudayakan peserta didik mebiasakan hidup dengan seni yang kreatif. Program ini bila dikaji dari sudut kurikulum terintegrasi tergolong jenis The Experience Curriculum, yaitu program yang cenderung mengutamakan kegiatan-kegiatan atau pengalaman peserta didik dalam rangka membentuk kemampuan yang terintegrasi dengan lingkungan maupun dengan potensi peserta didik. (Abdullah Idi, 2007: 172) Kurikulum ini pada hakikatnya peserta didik berbuat dan melakukan kegiatan-kegiatan yang sifatnya vokasional, tetapi tidak meniadakan aspek intelektual atau akademik peserta didik.

Global citizenship merupakan program kurikulum ekstrakurikuler yang bermanfaat untuk menanamkan jiwa kesadaran akan pentingnya perawatan alam, pelestarian hidup, dan reboisasi bumi. Program ini sesuai dengan program persistent life situations itu sendiri yang karakteristiknya adalah situasi yang diangkat senantiasa yang dihadapi manusia dalam hidupnya, masa lalu, saat ini, dan masa yang akan datang.

Begitu juga program community service yang merupakan program yang diberikan oleh sekolah untuk membiasakan peserta didik memberikan pelayanan sosial kepada masyarakat sekitar, baik berupa bhakti sosial atau pengabdian pada lembaga sosial kemasyarakatan.

c) Integrasi kurikulum dalam pembelajaran (within sigle discipline, across several disciplines, dan inside the mind of the learner)

Asas integrasi tidak hanya berlaku pada pengintegrasi visi-misi, kelembagaan, kurikulum sekolah dan dormitory, tetapi praktek integrasi kurikulum di kelas juga terjadi. Bentuk kurikulum terintegrasi dalam 
pembelajaran ada berbagai jenis yaitu within sigle discipline, across several disciplines, dan inside the mind of the learner. Misal pelaksanaan pembelajaran PAI, misal tentang asmaul husna, yaitu mengenal nama-nama Allah yang Agung kemudian diintegrasikan makna dari nama-nama Allah tersebut dengan kegiatan nyata seperti selalu berkasih sayang dengan sesama, selalu murah maaf, selalu bersikap adil dalam berbuat, selalu mengerjakan sesuatu secara bersih dan suci terutama berkaitan dengan kesehatan para siswa. Kemudian ada penjelasan secara kongkrit misalnya tentang sifat Allah yang Maha Suci dan Bersih, maka manusia atau siswa harus berperilaku bersih dan sehat sebagai hamba-Nya dalam kehidupan sehari-hari seperti kebersihan kamar tempat tinggal, kebersihan dan kesucian pakaian, bersih dari perbuatan keji dan mungkar, serta selalu mengutamakan pola hidup sehat. Jika diterapkan dengan pengembangan kurikulum terintegrasi Threaded Model (model tertali), yaitu pengajian suatu tema disiplin tertentu dengan mengaitkan berbagai penjelasan dari disiplin lain yang saling relevan dan mendukung. Lebih jelasnya digambarkan dengan bagan 3 .

Kelebihan dengan penggunaan model pembelajaran terintegrasi seperti di atas, peserta didik akan merasa mudah memahami pelajaran yang sifatnya abstrak agar lebih konkrit dan mengatahui faedah pelajaran yang didapat secara nyata dan langsung. Meskipun masih banyak model pembeljaran terintegrasi mungkin dengan pertimbangan yang cermat guru menggunakan threaded model dalam kurikulum terintegrasi ini.

Misal lagi pada pelaksanaan pembelajaran Biologi yang bisa diintegrasikan dengan mata pelajaran lain yaitu pendidikan kewarganegaraan, ilmu sosial, atau dengan religius values bagian dari mata pelajar Pendidikan Agama Islam. Contoh beberapa tema biologi tentang ekosistem yang mana manusia sebagai warga negara indonesia harus memperhatikan kelestarian hidup yang seimbang, apalagi bangsa indonesia yang memiliki sumber daya alam yang melimpah, maka siswa diberi spirit dan motivasi untuk lebih merasa memiliki alam Indonesia ini sebagai bagian hidupnya demi masa depan dan generasi mendatang. Ketika dijelaskan konsep ekosistem manusia dan lingkungan, para siswa mempelajarinya dengan semangat dan langsung tahu fungsinya mempelajari ilmu ekosistem, secara detail dari perspektif Biologi dan dampaknya pada kepribadian mereka sebagai warga negara Indonesia, atau juga dengan religius values bagaimana siswa 


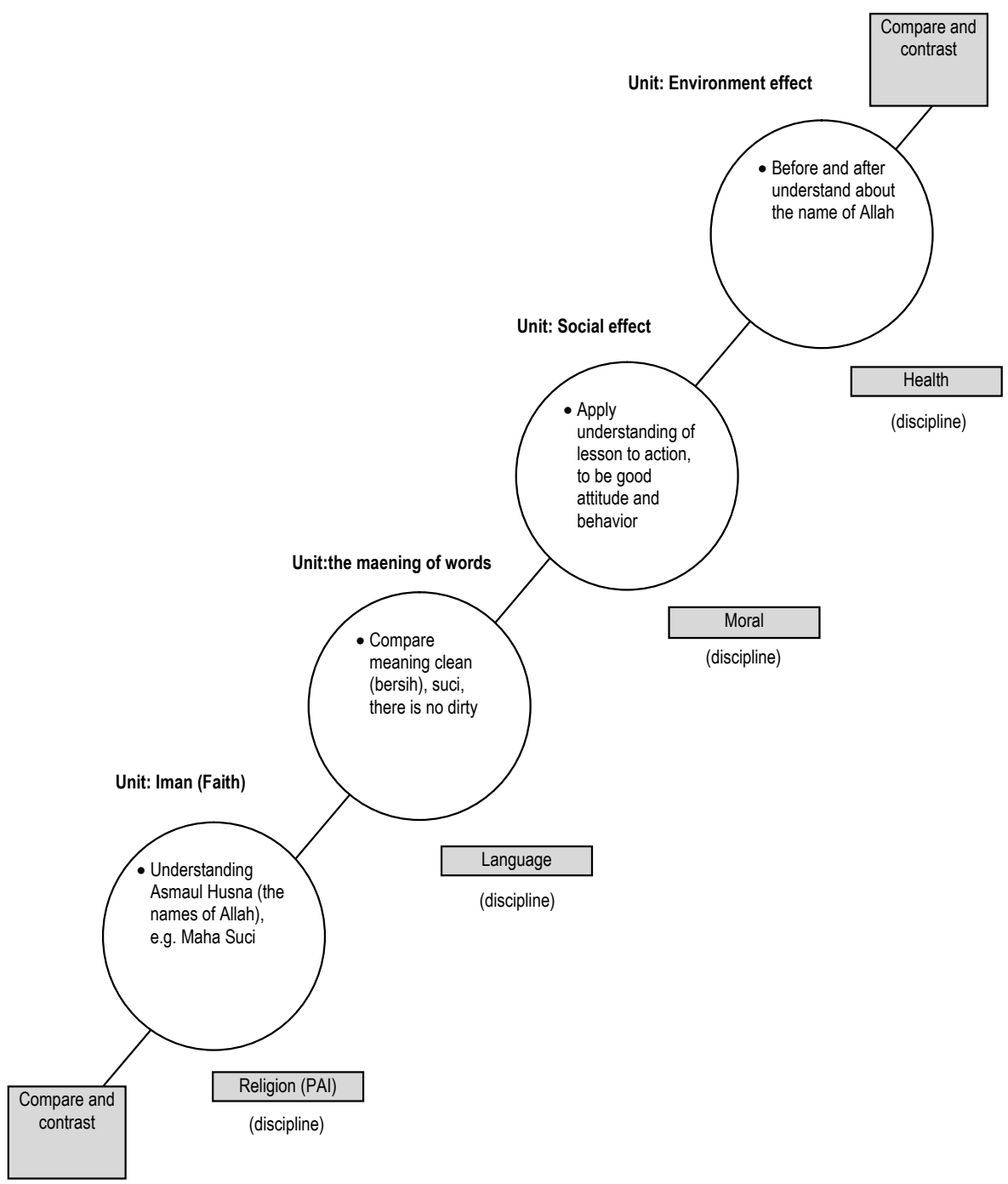

\section{Bagan 3: Kurikulum Terintegrasi Threaded Model Diadaptasi dan dimodifikasi dari (Robin Fogarty, How to Integrate the Curricula, 2009: 84.)}

mempelajari sub-sub anatomi manusia yang merupakan anugerah alam ciptaan Allah SWT, seperti bagaimana siswa harus mensyukuri, melihat sistem anatomi tubuh yang unik dan luar biasa, sehingga siswa akan lebih bisa menghargai apa yang mereka miliki dan yang mereka dapatkan sekarang untuk diperlihara dan dirawat baik anggota tubuhnya maupun perilaku 
apa yang harus dilakukan dalam kehidupan sosial. Jika digambarkan dalam bentuk bagan maka hasilnya sebagai berikut:

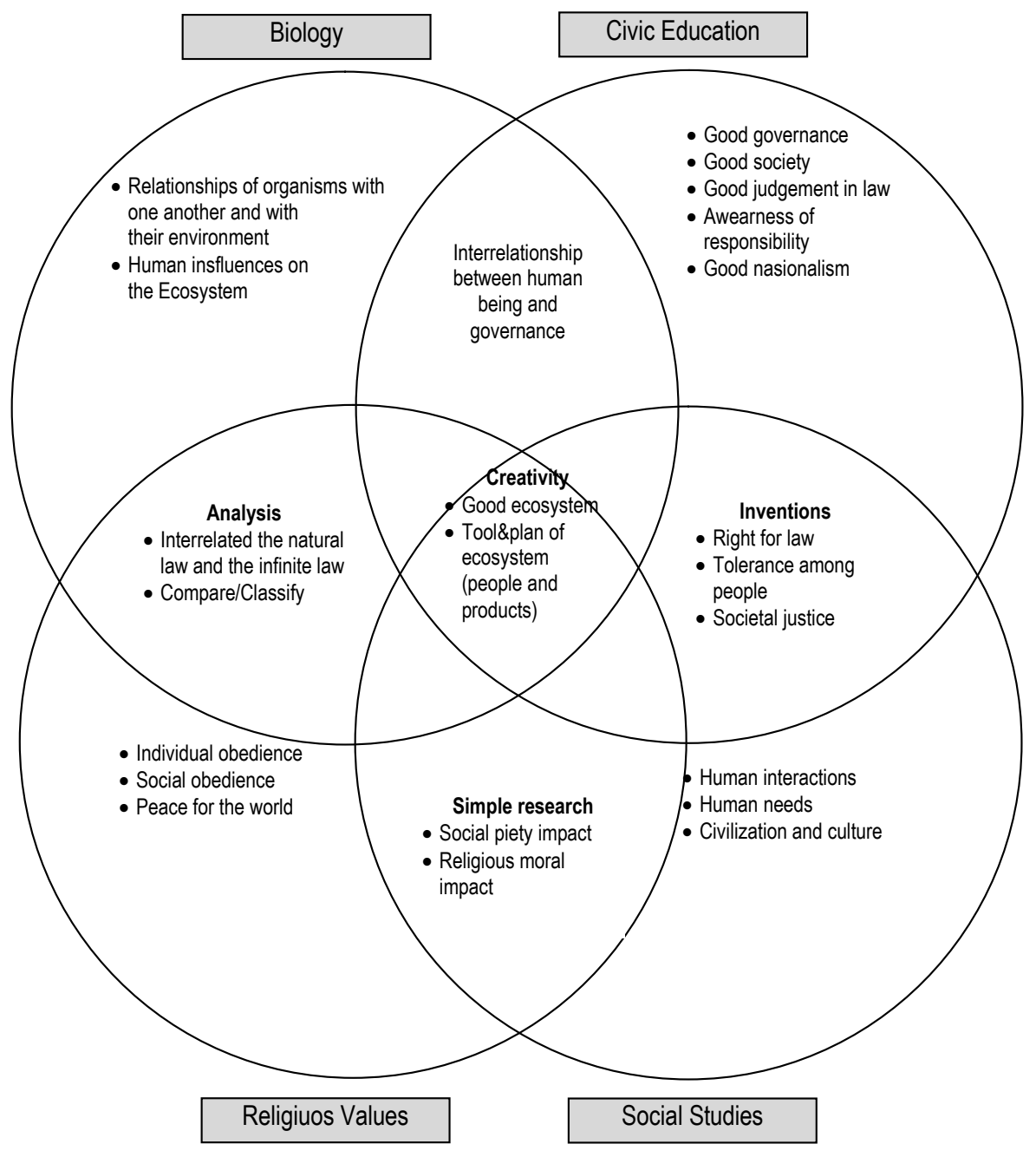

Bagan 3: Kurikulum Terintegrasi Integrated Model Diadaptasi dan dimodifikasi dari (Robin Fogarty, How to Integrate the Curricula, 2009: 98). 
Untuk memudahkan pengklasifikasian sub kajian yang bersangkutan, maka dibuat bagan sebagaimana di atas, sehingga ditemukan peleburan materi yang selaras dan mendukung pembelajaran tentang ekosistem yang terdapat pada mata pelajaran Biologi. Bidang kajian pengetahuan lain yang dianggap bisa diintegrasikan dengan sub kajian ekosistem dalam hal ini, mata pelajaran Biologi itu sendiri, pendidikan kewarganegaraan, pendidikan agama, dan ilmu sosial. Model pengembangan kurikulum terintegrasi yang sesuai pada kajian di atas yaitu integrated model (model terpadu). Model terpadu ini bagian dari kurikulum terintegrasi pada unitunit pembelajaran, yang masing-masing unit didukung oleh sejumlah mata pelajaran atau bidang studi. Tiap unit merupakan suatu masalah yang luas dan perlu dipecahkan, dan pemecahannya membutuhkan bahan dari setiap bidang studi. Itu sebabnya, urutan bahan, ruang lingkup dan penempatan bahan untuk setiap unit harus dirancang berdasarkan kebutuhan unit dan sistem instruksional yang dilaksanakan. Integrasi diciptakan dengan memusatkan pelajaran pada masalah tertentu yang memerlukan solusinya dengan materi atau bahan dari berbagai disiplin atau mata pelajaran. (Abdullah Idi, 2007: 141)

Ditinjau dari segi pendidikan kewarganegaraan ekosistem berkaitan dengan persoalan tatanan masyarakat yang baik, sehingga akan membentuk pemerintahan dan kenegaraan yang baik. Dari tampuk pemerintahan yang berwenang memutuskan kebijakan dan perundang-undangan untuk mengatur tatanan lingkungan sosial, tata kota, sanitasi, pertamanan, dan alam (cagar alam, hutan lindung, natural resources) yang baik pula. Perundang-undangan yang baik dan kebijakan yang baik bila dilakukan sesuai prosedur hukum yang benar, sehingga keadilan masyarakat dapat tercipta, dan penegakan hukum tidak tebang pilih. Dari kebiasaan masyarakat patuh pada hukum akan mempengaruhi kesadaran masyarakat bahwa untuk menegakkan jiwa dan cinta nasionalisme perlu dukungan hukum yang berdaulat.

Ekosistem dalam kajian Biologi termasuk kajian dari sub cabang Biologi tentang ekologi yaitu ilmu yang mempelajari tentang lingkungan hidup, baik manusia, hewan dan tumbuhan. Manusia sebagai makhluk yang paling menguasai kehidupan di dunia ini dibanding makhluk lain, maka sejauh mana mereka menata dan melestarikan serta memberikan 
dampak positif. Ditinjau dari sudut pendidikan agama, manusia sebagai khalifah fil ardhi memiliki kewajiban beribadah yaitu ibadah makhdhoh dan ghoiru makhdhoh. Ibadah makhdhoh adalah ibadah yang dilakukan manusia secara langsung kepada Allah SWT, seperti shalat, puasa, haji dan lain sebagainya (atau populer dengan istilah hablu mina Allah). Sedangkan ibadah ghoiru makhdhoh adalah ibadah yang dilakukan manusia tidak berinteraksi langsung dengan Allah SWT, yaitu ibadah yang berbentuk amal kebaikan dan kebajikan kepada seluruh makhluk dan alam dengan harapan mendapatkan ridho, rahmat dan pahala dari Allah (atau populer dengan istilah hablu minan nas wa hablu minal 'alam). Dari sudut pandang ini, maka ekosistem bagian peran manusia untuk mengaturnya menjadi lebih baik sesuai fitrah manusia yang menginginkan alam ini menjadi tertata baik, dan terdapatnya tanggung jawab manusia untuk menjaga ataupun melestarikan alam (baik cagar alam/satwa, maupun cagar budaya) sebagai bentuk ibadah ghoiru makhdhoh yang harus dikerjakan. Karena agama mendorong manusia untuk menjadi sholih, yang mana makna sholih tidak sekedar melakukan ritual ibadah formal saja, tetapi juga menjadi manusia yang bermanfaat seluas-luasnya tanpa terkotak-kotak oleh kepentingan sesaat.

Sudut pandang ilmu sosial tentang ekosistem juga sangat memberikan konstribusi, sebagaimana diketahui dalam lingkungan selalu ada interaksi yang memberikan dampak baik positif maupun negatif. Dampak positif bisa selalu dipertahankan dan dampak negatif harus diantisipasi sedini mungkin. Dalam kajian ilmu sosial, ekosistem erat kaitannya dengan kebutuhan manusia ( human needs) yang akan menyisakan residu bagi lingkungan baik berupa material dan non-material. Dari situ, manusia dituntut untuk bisa menanggulangi residu yang diciptakannya sendiri dengan pengetahuan yang dimilikinya. Manusia juga memiliki hasrat untuk menjadi lebih baik dari pendahulunya, sehingga mereka membangun sebuah budaya dan peradaban yang menunjang lingkungan hidupnya. Di sinilah perhatian dicurahkan pada persoalan ekosistem, bagaimana manusia sanggup menata kebutuhan infrastrukturnya, kebutuhan natural resources-nya, kebutuhan teknologinya, kebutuhan kesehatannya dan kebutuhan seni-hiburannya dengan kajian ilmu sosial kemanusiaan yang tepat. 
Setelah ada pengintegrasian kajian tentang ekosistem dari empat sudut disiplin ilmu yaitu pendidikan kewarganegaraan, biologi, pendidikan agama, dan ilmu sosial, maka akan ditemukan hasil integrasi atau peleburan subsub tema kajian seperti pengintegrasian sudut pandang dari pendidikan kewarganegaraan dengan biologi, ditemukan bagaimana membangun sebuah tata kelola negara baik infrastruktur dan kebijakan yang memperhatikan aspek keadilan kemanusiaan dan kelestarian lingkungan hidup. Begitu juga ketika ada persinggungan sudut pandang dari disiplin biologi dan pendidikan agama, ditemukan hasil integrasi berupa sub tema kewajiban manusia untuk memahami dasar-dasar hukum yang ditentukan oleh Allah berupa wahyu dan hadis yaitu ayatul qouliyah dan hukum alam yaitu ayatul kauniyah serta memahami bagaimana mengkombinasikan dan memposisikan kedua dasar hukum tersebut. Persinggungan sudut pandang dan integrasi juga terjadi pada pendidikan agama dan ilmu sosial yang melahirkan sub tema tentang dampak sosial dan lingkungan orang yang beragama, dan dampak moral relegius terhadap alam lingkungan hidup. Sedangkan integrasi sudut padang disiplin ilmu sosial dan pendidikan kewarganegaraan menghasilkan sub tema-sub tema tentang kebijakan yang tepat dalam menata ekosistem, toleransi antar warga untuk menciptakan ekosistem yang baik, dan membangun sebuah kebudayaan dan peradaban manusia dengan mengedepankan penataan ekosistem yang baik untuk generasi selanjutnya.

Dari persinggungan dan integrasi masing-masing disiplin akan menjadi problem solving pada tema besar yaitu ekosistem yang akan dikaji secara spesifik, useful dan aplikatif. Penjabaran tema besar ekosistem akan diurai secara konseptual baik menciptakan maupun menanggulangi bila ada kerusakan ekosistem, dan bagaimana menciptakan rancang bangun ekosistem secara aplikatif hingga menghasilkan perencanaan dan alat/ fasilitas yang dibutuhkan.

\section{b. Perencanaan Kurikulum Terintegrasi}

Perencanaan kurikulum terintegrasi bila diklasifikasikan pada model-model perencanaan kurikulum, maka secara substantif termasuk perencanaan kurikulum model interaktif rasional, yaitu memandang rasionalitas sebagai tuntutan kesepakatan antara pendapat-pendapat 
yang berbeda yang bersumber dari berbagai disiplin mata pelajaran, yang tidak mengikuti urutan logik karena berpaku pada topik atau tema persoalan. (Oemar Hamalik, 2008: 153) Model interaktif rasional ini, asumsi rasionalitasnya menekankan pada respons fleksibelitas kurikulum dan mengedepankan inisiatif pada tingkat sekolah atau tingkat lokal. Namun secara prosedural kurikulum terintegrasi termasuk model perencanaan rasional deduktif, yang menitikberatkan logika dalam merancang program kurikulum dan bertitik-tolak dari spesifikasi tujuan. (Oemar Hamalik, 2008: 153)

Perencanaan pengembangan kurikulum terintegrasi yang dilakukan di sekolah/madrasah harus diawali dengan penyelenggaraan workshop pengembangan kurikulum secara tahunan. Perencanaan kurikulum mengacu dari visi misi lembaga, yang penekanannya pada pembentukan kepribadian yang berdaya saing baik nasional maupun internasional, penanaman nilainilai kepemimpinan dan pengembangan kreativitas atau skill peserta didik yang dimilikinya.

Kepala sekolah sesuai dengan perannya sebagai manajer sekolah menitikberatkan pada perencanaan untuk melaksanakan kurikulum dalam sistem sekolah, melakukan koordinasi kegiatan guru-guru, menata dan membina organisasi guru dan organisasi pembelajaran peserta didik, membina sistem komunikasi yang efektif di lingkungan sekolah antara sekolah dan masyarakat serta lembaga-lembaga lainnya, melakukan supervisi bagi guru-guru bidang studi dan menilai kegiatan guru-guru serta melaksanakan penilaian secara keseluruhannya. (Oemar Hamalik, 2008: 173) Sedangkan tugas guru menyusun perencanaan kegiatan tahunan, semester, bulanan, dan mingguan yang terkait dalam pelaksanaan instruksional dalam bidang studi atau kelas yang menjadi tanggung jawabnya.

Dalam perencanaan kurikulum sekolah/madrasah bila diklasifikasi melahirkan kurikulum terintegrasi yang mengemas written curriculum, experencial curriculum dan hidden curriculum yang dilaksanakan secara sinergis, meskipun pelaksanaannya sekolah melakukan modifikasimodifikasi tertentu sesuai karakter sekolah.

Untuk menunjang perencanaan kurikulum terintegrasi yang baik, maka diperlukan manajemen komponen-komponen pendidikan lainnya di sekolah/madrasah, sebagaimana bagan di bawah ini: 


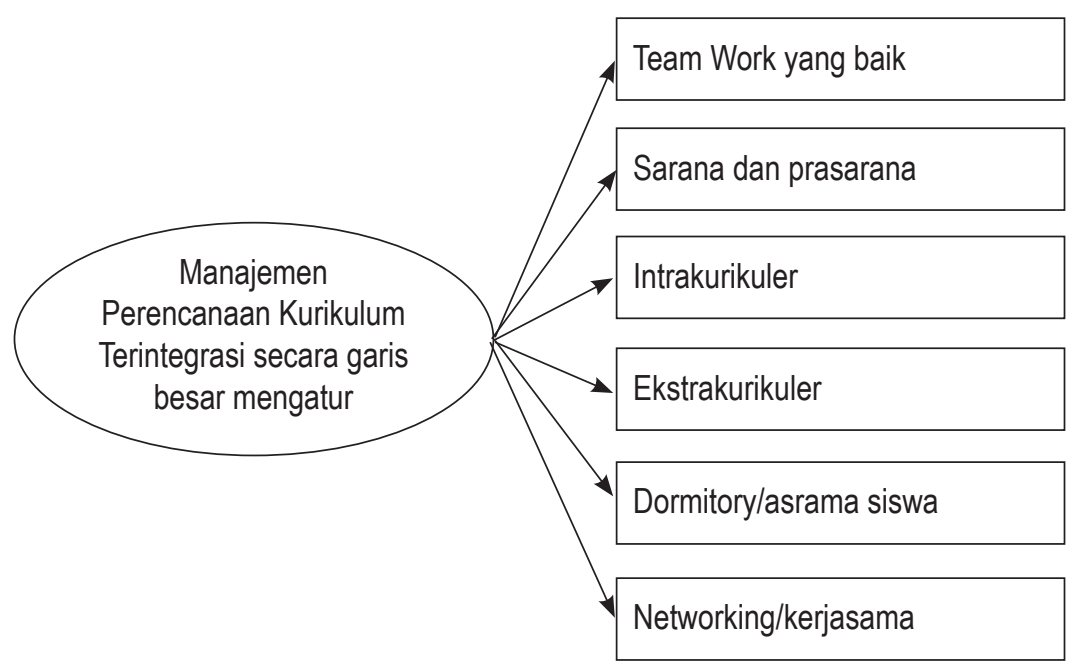

\section{c. Pelaksanaan Kurikulum Terintegrasi}

Pelaksanaan kurikulum direalisasikan dalam proses belajar mengajar sesuai dengan prinsip-prinsip dan tuntutan kurikulum yang telah dikembangkan bagi suatu jenjang pendidikan atau sekolah/madrasah. Pelaksanaan kurikulum dibagi menjadi dua tingkatan yaitu pelaksanaan kurikulum tingkat sekolah dan tingkat kelas. Dalam tingkat sekolah yang berperan adalah kepala sekolah dan wakilnya, sedangkan pada tingkat kelas yang berperan adalah guru.

Bentuk pembelajaran terintegrasi yang dilakukan hakikatnya merupakan suatu sistem pembelajaran yang memungkinkan peserta didik baik secara individual maupun kelompok aktif mencari, menggali, dan menemukan konsep serta prinsip secara holistik dan otentik. Melalui pembelajaran terintegrasi peserta didik dapat memperoleh pengalaman langsung, sehingga dapat menambah kekuatan untuk menerima, menyimpan dan memproduksi kesan-kesan tentang hal-hal yang dipelajarinya. Dengan demikian, peserta didik terlatih untuk dapat menemukan sendiri berbagai konsep yang dipelajari secara holistik, bermakna, dan otentik secara aktif.

Pembelajaran di kelas yang dilakukan di sekolah/madrasah, bila dipilah sesuai model pengembangan kurikulum terintegrasi akan terpetakan secara mudah. Beberapa bagian kurikulum terintegrasi bisa dilaksanakan 
secara fleksibel di dormitory (asrama), bahwa ada kegiatan akademik yang dilaksanakan di asrama dan yang bisa menunjang kurikulum yang dilaksanakan sekolah untuk mencapai visi, misi dan tujuan sekolah seperti pelatihan dan bimbingan leadership secara intensif, pelatihan dan pembinaan kewirausahaan yang dipraktekkan secara intensif, dan kegiatan lainnya guna membentuk dan membina watak kepribadian dan akhlak mulia selama di asrama. Dengan demikian, proses pembelajaran tidak membuat siswa jenuh hanya dengan satu setting di kelas saja. Pelaksanaan kurikulum terintegrasi lebih variatif dan banyak menggabungkan berbagai strategi dan metode pembelajaran.

Bila dicermati secara mendalam proses pelaksanaan kurikulum terintegrasi sesuai alur dan perangkat-perangkat, maka akan didapat prosedur ini pengembangan kurikulum terintegrasi, sebagaimana yang penulis temukan adanya The Spiral Cycle Model of Integrated Curriculum Process, bila dibagankan alurnya sebagai berikut:

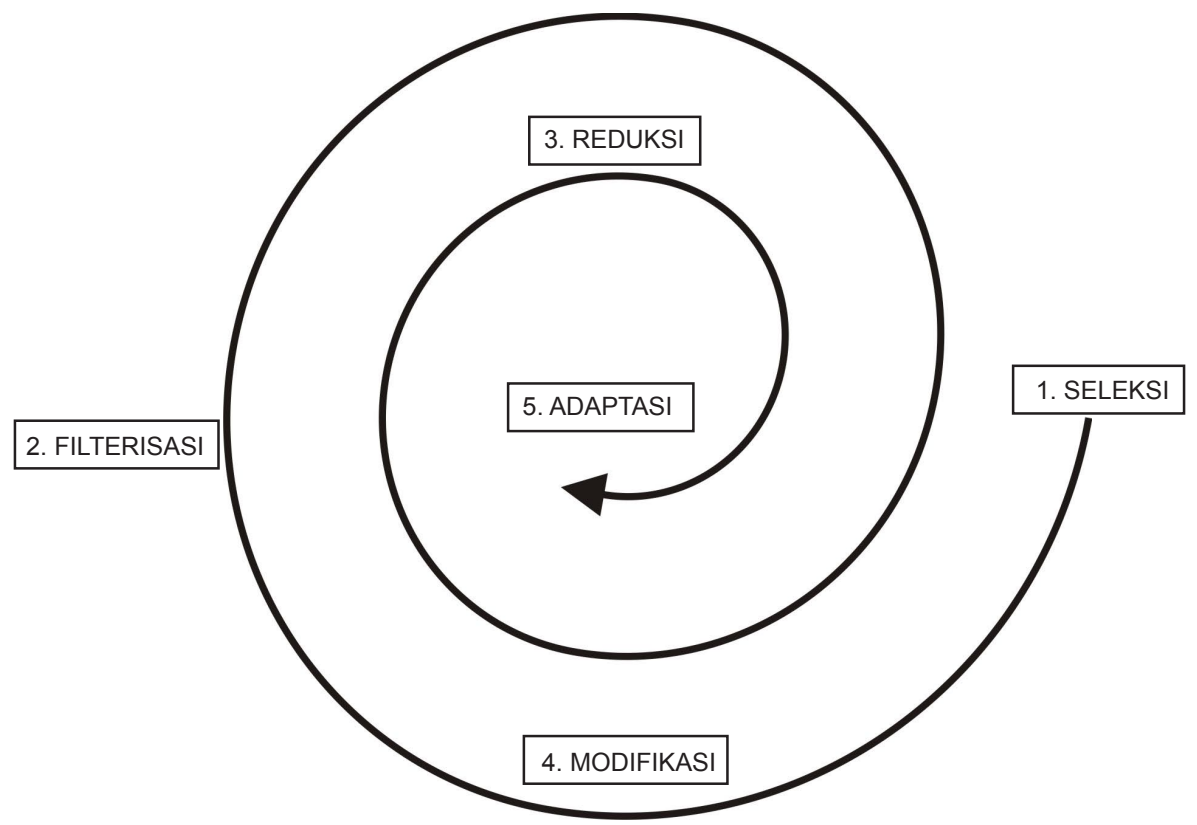

Bagan 4: The Spiral Cycle Model of Integrated Curriculum Process 
Bila dijelaskan keterangan pada bagan di atas yaitu: (1) SELEKSI: yaitu pemilihan bidang disiplin ilmu yang dianggap berkaitan, melengkapi, memberi sudut pandang yang bermanfaat dan komprehensip terhadap tema/topik dalam pembelajaran yang akan diberikan di kelas; (2) FILTERISASI: yaitu proses penyaringan kajian dari setiap disiplin ilmu lain yang dianggap melengkapi tadi agar terjadi pemfokusan kajian pada tema/topik yang telah ditentukan agar tidak melebar dan terjebak pada sub disiplin ilmu lain yang tidak diperlukan; (3) REDUKSI: yaitu proses tindak lanjut filterisasi dengan melakukan pengabaian, pembuangan, dan penglupasan kajian yang tidak substantif dari disiplin ilmu lain, sehingga semakin jelas konten substantif yang dibutuhkan dari ilmu lain untuk kajian topik yang telah ditentukan; (4) MODIFIKASI: yaitu pembentukan model kurikulum terintegrasi yang diinginkan secara fleksibel dan tepat sasaran dengan visi, misi dan tujuan lembaga pendidikan; (5) ADAPTASI: yaitu penentuan dan penetapan kurikulum terintegrasi yang siap pakai, berupa dokumen kurikulum untuk diimplementasikan dalam pembelajaran.

\section{d. Evaluasi Kurikulum Terintegrasi}

Tujuan pendidikan beserta kebijakan-kebijakan penyertanya merupakan acuan dari proses evaluasi yang dilaksanakan. Begitu pula Muhammad Ali berpendapat, bahwa evaluasi kurikulum harus mengacu pada prinsip: (1) evaluasi mengacu pada tujuan (2) evaluasi bersifat komprehensif dan (3) evaluasi dilaksanakan secara objektif. (Muhammad Ali, 2009: 127) Penilaian komprehensif dilakukan tidak hanya pada ruangan kelas tetapi juga pada proses pembelajaran di luar kelas, atau bahkan berdasar pada panilaian teman sejawat yang dilakukan siswa sendiri dengan adanya student advisor.

Peranan evaluasi kurikulum bagi pimpinan, berkenaan dengan hal yaitu: evaluasi sebagai moral judgement, evaluasi dan penentuan keputusan, serta evaluasi dan konsensus nilai. (Nana Syaodih Sukmadinata, 2005: 180) Dari peranan kepemimpinan ini dijadikan feedback untuk menyusun perencanaan kurikulum terintegrasi selanjutnya. Bagi guru, penyelenggaraan evaluasi hasil penerapan pengembangan kurikulum dalam satu semester, yaitu: evaluasi formatif dan evaluasi sumatif. (Arikunto, 1987: 142) Evaluasi formatif dan sumatif itu dilaksanakan dengan bentuk penilaian tes, baik 
tulis, praktek maupun portofolio. Guru dalam melakukan evaluasi harus menggunakan pedoman berbentuk form untuk memetakan ranah apa saja yang akan dievaluasi dari peserta didik.

Dalam evaluasi kurikulum terintegrasi, penilaian pencapaian kompetensi dasar peserta didik dilakukan berdasarkan indikator. Penilaian dilakukan dengan menggunakan tes dan non tes dalam bentuk tertulis maupun lisan, pengamatan kinerja, pengukuran sikap, penilaian hasil karya berupa tugas, proyek dan/atau produk, penggunaan portofolio dan penilaian diri. Evaluasi ranah kognitif seperti adanya ujian tulis maupun lisan baik ulangan harian, UTS maupun UAS, sedang evaluasi afektif diukur dengan instrumen yang berbentuk form untuk menilai setiap poin-poin sikap maupun kepribadian yang berkembang pada setiap siswa, bisa guru yang menilai atau siswa dengan bentuk penilaian teman sejawat. Begitu juga untuk evaluasi ranah psikomotik di desain seperti pada penilaian efektif dengan adanya instrumen yang poin-poinnya tentang ketangkasan siswa dalam menjalankan ajaran-ajaran agama baik individu maupun sosial, dalam beretika atau berakhlak, tanggung jawabnya, kedisiplinannya dan sebagainya.

Peran guru BK juga sangat dibutuhkan, sehingga poin-poin tersebut terekam secara digital di komputer perkembangan ranah afektif dan psikomotorik setiap siswa, dan ada punishment-punishment tertentu baik yang bersifat teguran atau nasehat hingga sampai memanggil orang tuanya. Sedangkan evaluasi kurikulum terintegrasi dalam bentuk evaluasi dengan tes maupun non tes pada seluruh ranah kognitif, afektif dan psikomotorik. Lebih jelasnya digambarkan beberapa contoh form penilaian evaluasi dalam tabel di bawah ini.

\section{Tabel 4: Contoh Tes Tertulis (kognitif)}

\begin{tabular}{|c|c|c|}
\hline NO & Butir-butir Soal & Kunci Jawaban \\
\hline 1 & $\begin{array}{l}\text { Nama-nama Allah yang berarti kasih } \\
\text { sayang }\end{array}$ & Ar-Rahman dan Ar-Rohim \\
\hline 2 & $\begin{array}{l}\text { Macam-macam bentuk ibadah kepada } \\
\text { Allah }\end{array}$ & $\begin{array}{l}\text { Ibadah makhdhoh dan ibadah } \\
\text { ghoiru makhdhoh }\end{array}$ \\
\hline 3 & Contoh-contoh ibadah ghoiru makhdhoh & $\begin{array}{l}\text { Bersedekah, bhakti sosial, berbuat } \\
\text { baik pada tetangga dan manusia } \\
\text { lainnya, menjada kebersihan dan } \\
\text { kelestarian lingkungan }\end{array}$ \\
\hline
\end{tabular}


Tabel 5: Contoh Tes Sikap (afektif)

\begin{tabular}{|c|c|c|c|c|c|}
\hline NO & Pernyataan & ss & S & TS & STS \\
\hline 1 & $\begin{array}{l}\text { Mencintai dan menghormati orang lain baik muslim } \\
\text { maupun non-muslim seperti mencintai dan menghormati } \\
\text { diri kita sendiri }\end{array}$ & & & & \\
\hline 2 & $\begin{array}{l}\text { Mendahulukan ibadah kepada Allah meskipun kita } \\
\text { dalam keadaan terdesak hingga kemiskinan dan } \\
\text { kelaparan atau orang/keluarga yang kita sayangi } \\
\text { direnggut nyawanya }\end{array}$ & & & & \\
\hline 3 & $\begin{array}{l}\text { Rela berbagi makanan kepada orang lain meskipun kita } \\
\text { dan keluarga kita dalam keadaan kelaparan juga }\end{array}$ & & & & \\
\hline
\end{tabular}

\section{Keterangan:}

SS : Sangat Setuju

S: : Setuju

TS : Tidak Setuju

STS : Sangat Tidak Setuju

\section{Skor Tes Sikap}

$=50$

$=40$

$=10$

$=0$

Tabel 6: Contoh Tes Perbuatan (Psikomotorik)

\begin{tabular}{|c|l|l|l|l|l|c|}
\hline \multirow{2}{*}{ NO } & \multirow{2}{*}{ Nama Siswa } & \multicolumn{5}{|c|}{ Kemampuan Praktek Shalat dan Membaca Al-Qur'an } \\
\cline { 3 - 7 } & & $\mathbf{1}$ & $\mathbf{2}$ & $\mathbf{3}$ & $\mathbf{4}$ & $\mathbf{5}$ \\
\hline 1 & Son Ardinata & & & & & \\
\hline 2 & Muhammad Fajar & & & & & \\
\hline 3 & Ahmad Basyar & & & & & \\
\hline 4 & dst. & & & & & \\
\hline
\end{tabular}

Keterangan:

1: Praktek Shalat Baik dan Membaca Al-Qur'an Baik

2: Praktek Shalat Baik dan Membaca Al-Qur'an Kurang Baik

3: Praktek Shalat Kurang Baik dan Membaca Al-Qur'an Baik

4: Praktek Shalat Kurang Baik dan Membaca Al-Qur'an Kurang Baik

5: Tidak Bisa Praktek Shalat dan Tidak Bisa Membaca AI-Qur'an
Skor Tes Perbuatan

$$
\begin{aligned}
& =80-90 \\
& =70-79 \\
& =60-69 \\
& =50-59 \\
& =<50
\end{aligned}
$$

Sedangkan penilaian yang dilakukan guru dengan Tanpa Tes, berdasarkan pada pedoman berikut, yaitu:

1. Penilai yang dilakukan oleh guru dengan menggunakan metode portofolio dimana guru mencatat dan mendeskripsikan dari siswa, yaitu: 

a. Apa yang diamati
b. Laporan dari rekan guru dan pegawai sekolah
c. Laporan dari orang tua siswa dan siswa sendiri

2. Penilaian yang dilakukan guru berdasarkan pada tugas atau pengalaman belajar yang harus dilalui siswa, dengan bentuk laporan belajar tertulis:

a. Tugas belajar di rumah baik dilakukan secara individu maupun kelompok

b. Penelitian sederhana yang dilakukan di luar kelas baik secara individu maupun kelompok.

c. Tugas belajar berbasis produk seperti penyelenggaraan pameran keterampilan atau plan business yang dilakukan di luar kelas yang disertai laporan tertulis secara kelompok.

Hasil dari evaluasi yang telah dilaksanakan di sekolah, digunakan sebagai bahan pertimbangan dan tolak ukur keberhasilan penerapan kurikulum terintegrasi sesuai perencanaan dan tujuan institusional yang dicita-citakan. Keberhasilan penerapan kurikulum terintegrasi juga akan memberikan dampak positif bagi peserta didik tentunya, dari seluruh segi prestasi, moral dan kreativitas/keterampilan.

\section{Kesimpulan}

Berdasarkan pemaparan dan hasil penelitian di tulisan ini dengan kajian pengembangan kurikulum terintegrasi di sekolah/madrasah, maka dapat diambil kesimpulan sebagai berikut:

1. Konsep pengembangan kurikulum terintegrasi di sekolah/madrasah, diformulasikan dengan: a) konsepsi visi dan misi yang terintegrasi, b) integrasi kelembagaan (sekolah dan dormitory), c) integrasi kurikulum (KTSP dan IGCSE, intrakurikuler dan ekstrakurikuler), dan proses pembelajaran/pengajaran yang terintegrasi.

2. Perencanaan kurikulum terintegrasi di sekolah/madrasah, secara substantif termasuk perencanaan kurikulum model interaktif rasional, sedangkan secara prosedural termasuk model perencanaan rasional 
deduktif. Perencanaan kurikulum terintegrasi mengacu pada visi dan misi sekolah, penyelarasan kurikulum KTSP dan IGCSE, penyelarasan kurikulum intrakurikuler dan ekstrakurikuler, pembuatan lesson plan yang integratif, pelaksanaan workshop dan musyawarah guru bidang studi secara berkala dalam pengembangan SK dan KD, dan penyusunan dokumen kurikulum terintegrasi.

3. Pelaksanaan kurikulum terintegrasi, berdasar pada dokumen kurikulum terintegrasi. Pelaksanaan kurikulum terintegrasi terwujud pada unit-unit pembelajaran, yang masing-masing unit didukung oleh sejumlah mata pelajaran atau bidang studi. Proses pembelajarannya juga dilakukan secara terintegrasi baik metode, strategi, sumber, media, dan praktek-praktek exhibition dan research sederhana yang dilakukan di lapangan.

4. Evaluasi kurikulum terintegrasi, dilakukan berdasarkan pada perencanaan dan pelaksanaan yang telah dilakukan dengan model evaluasi tes maupun non-tes yang teridir dari bentuk tertulis maupun lisan, pengamatan kinerja, pengukuran sikap, penilaian hasil karya berupa tugas, proyek dan/atau produk, penggunaan portofolio dan penilaian diri.

\section{Daftar Rujukan}

Abdullah Idi, Pengembangan Kurikulum: Teori dan Praktik, (Yogyakarta: Ar-Ruzz Media, 2007).

Ali Idrus, Manajemen Pendidikan Global: Visi, Aksi dan Adaptasi,(Jakarta: Gaung Persada Press, 2009).

Bogdan, R. C. \& Biklen, S. K., Qualitative Research For Education an Introduction to theory and Methods, (London: Allyn and Bacon. Inc., 1982).

E. Mulyasa, Manajemen dan Kepemimpinan Kepala Sekolah, (Jakarta: Bumi Aksara, 2011).

Lexy J. Moleong, Metode Penelitian Kualitatf: Edisi Revisi (Bandung: PT Remaja Rosdakarya, 2006). 
Lias Hasibuan, Kurikulum dan Pemikiran Pendidikan, (Jakarta: Gaung Persada Press, 2010).

Ministry of Education Malaysia, Integrated Curriculum for Secondary Schools,

(Kuala Lumpur: Ministry of Education Malaysia, 2002).

Muhaimin, Pengembangan Kurikulum Pendidikan Islam: di Sekolah, Madrasah dan Perguruan Tinggi, (Jakarta: Rajawali Pers, 2009).

Muhammad Ali, Pengembangan Kurikulum di Sekolah, (Bandung: Sinar Baru Algensindo, 2009).

Nana Syaodih Sukmadinata, Pengembangan Kurikulum: Teori dan Praktek, (Bandung: PT. Remaja Rosdakarya, 2005).

Oemar Hamalik, Manajemen Pengembangan Kurikulum, (Bandung: UPI dan PT Remaja Rosdakarya, 2008).

Robert C. Bogdan dan Biklen, Qualitative Research for Education: An Intriduction to Theory and Suharsimi Arikunto, Prosedur Penelitian Suatu Pendekatan Praktek,. (Jakarta: PT. Rineka Cipta, 1996).

Robin Fogarty, How to Integrate the Curricula, (USA: CorwinPress, 2009).

Rusman, Manajemen Kurikulum, (Jakarta: PT RajaGrafindo Persada, 2009).

Sudarwan Danim dan Suparno, Manajemen dan Kepemimpinan Transformasional Kekepalasekolahan: Visi dan Strategi Sukses Era Teknologi, Situasi Krisis, dan Internasionalisasi Pendidikan, (Jakarta: PT Rineka Cipta, 2009).

Suharsimi Arikunto, Prosedur Penelitian: Suatu Pendekatan Praktis, (Jakarta: PT Bima Karya, 1987).

Trianto, Model Pembelajaran Terpadu: Teori dan Praktek, (Jakarta: Prestasi Pustaka, 2007).

Unesco, Training Educational Personnel for Integrated Curriculum, (Bangkok: Unesco Regional Office for Education in Asia and the Pacific, 1984). 
Wina Sanjaya, Kurikulum dan Pembelajaran: Teori dan Praktik Pengembangan Kurikulum Tingkat Satuan Pendidikan (KTSP), (Jakarta: Kencana, 2009).

Yin, R.K.,. Studi Kasus: Desain dan Metode, Terjemahan M. Djauzi Mudzakir, (Jakarta: Raja Grafindo Persada, 2000). 